NBSIR 76-1027

\title{
A Survey of Manufacturers' Views on the ETIP Procurement Experiment Volume Three: Ranges
}

P. Clare Goodman

Product Systems Analysis Division

Center for Consumer Product Technology Institute for Applied Technology

National Bureau of Standards

Washington, D. C. 20234

February 1976

Final Report

Prepared for

Experimental Technology Incentives Program

National Bureau of Standards

Washington, D. C. 20234 



\section{A SURVEY OF MANUFACTURERS' \\ VIEWS ON THE ETIP \\ PROCUREMENT EXPERIMENT \\ VOLUME THREE: RANGES}

P. Clare Goodman

Product Systems Analysis Division

Center for Consumer Product Technology

Institute for Applied Technology

National Bureau of Standards

Washington, D. C. 20234

February 1976

Final Report

Prepared for

Experimental Technology Incentives Program

National Bureau of Standards

Washington, D. C. 20234

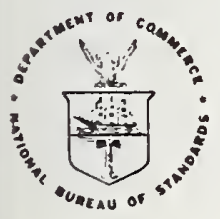

U.S. DEPARTMENT OF COMMERCE, Elliot L. Richardson, Secrotery 
ACKNOWLEDGEMENTSS

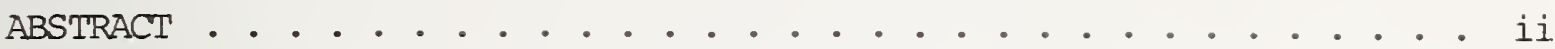

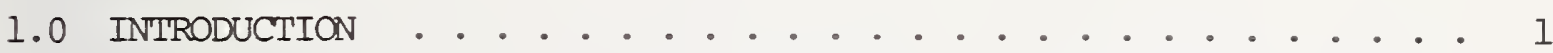

1.1 Background . . . . . . . . . . . . . . . . . . . 1

1.2 Factors to be Evaluated . . . . . . . . . . . . . . . 2

1.3 Range Procurement Methodology . . . . . . . . . . . . 3

2.0 METHODOLOGY . . . . . . . . . . . . . . . . . . 3

2.1 Questionnaire Development . . . . . . . . . . . 3

2.2 Sample Selection . . . . . . . . . . . . . . . . . 3

2.3 Data Collection . . . . . . . . . . . . . . . 4

3.0 SURVEY RESULTS . . . . . . . . . . . . . . . . . 5

3.1 Background: The Range Industry . . . . . . . . . . . 5

3.2 The Government Procurement Mechanism . . . . . . . . . . . 7

3.2.1 Industry Problems . . . . . . . . . . . 7

3.2.2 Factors in the Decision to Bid on an IFB. . . . . 10

3.3 Life-cycle costing . . . . . . . . . . . . . . 12

3.3.1 The LCC Formula . . . . . . . . . . . 12

3.3.2 Maintenance Data .. . . . . . . . . . 13

3.3.3 Warranty Information ............. 14

3.4 Bidders Conferences . . . . . . . . . . . . . . . 14

3.5 Advertising . . . . . . . . . . . . . . . 15

3.6 Engineering Considerations . . . . . . . . . . . . . 16

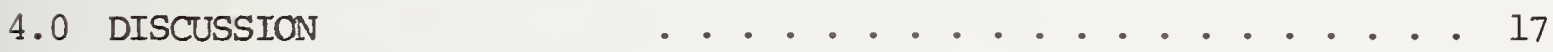

APPENDIX A - Questionnaire for Manufacturers of Gas and Electric Ranges 19 APPENDIX B - List of Firms that Participated in the Survey . . . . . . 23 APPENDIX C - Letter Mailed to Request Participation . . . . . . . . . 24 APPENDIX D - Introductory Paragraph Read to Respondents . . . . . . 25 APPENDIX E - Methodology for Calculating LCC . . . . . . . . . . . . . 26 APPENDIX F - Govermment Regulation on Advertising . . . . . . . . . . 27 



\section{ACKNOWLEDGEMENTS}

The author wishes to thank Dr. Charles Fried, Project Leader, for providing administrative assistance and guidance throughout the survey. Dr. Fried furnished valuable information to the project staff and edited the manuscripts.

Mr. Joseph Staugaitis, deserves special thanks for his work in assisting in the design of the survey, and contributing to the data analysis and interviews. Theodore Fody, Project Monitor, is acknowledged for his helpful guidance and assistance throughout the project.

The author would also like to thank Mrs. Mary Abbott for her secretarial assistance in planning interview trips and in the preparation of this manuscript. 
A SURVEY OF MANUFACTURERS' VIEWS ON THE ETIP PROCUREMENT EXPERTMENT VOLUME THREE: RANGES

P. Clare Goodman

Abstract

This report describes the findings of a survey of nine gas and electric range manufacturers by the center for Consumer Product Technology. The survey was conducted for the Experimental Technology Incentives Program (ETIP) as part of its evaluation of a Federal Supply Service (FSS) procurement of ranges. Survey questions were designed to obtain manufacturers' views on the use of Government procurement policies to increase the rate of introduction of new technologies into the consumer marketplace. The questions covered the following areas: (1) reasons for participation or non-participation of a manufacturer in the ETIP experiment; (2) problems a manufacturer encounters with existing Federal procurement practices; (3) acceptability of using life-cycle costing in the bidding procedure; and (4) effect of the most recent Government procurement on present and future company operations. Results of the survey are reported, and implications are drawn for future ETIP studies of Government procurement activities.

Key words: Energy-efficient products; Experimental Technology Incentives Program; gas and electric ranges; life-cycle costing; procurement experiments. 
A Survey of Manufacturers' Views on the ETIP Procurement Experiment Volume Three: Ranges

\section{Introduction}

\subsection{Background}

The Experimental Technology Incentives Program (ETIP) of the National Bureau of Standards (NBS) is part of the Federal Government's efforts to determine what can be done to increase the rate at which new technologies are introduced into the marketplace. The ETIP is part of a continuing effort by the Federal Government to "work as a more effective partner with the private sector in the development and application of science and technology to strengthen the nation's economy and improve the quality of life." I/

ETIP has selected Federal procurement practices as an area requiring special study. Five procurement experiments are currently underway to determine whether it is feasible to stimulate the development, production, and marketing of energy-efficient products through the use of Government purchasing practices. Each experiment is planned to last three years to allow sufficient time for the industry involved to introduce technological innovations.

These five procurements were performed in cooperation with the Federal Supply Service (FSS) of the General Services Administration (GSA) . They were intended to determine if changes in procurements, such as the use of a modified life-cycle cost formula in the bidding procedure, would increase the availability and recognition of energy-efficient appliances in the marketplace.

The life-cycle cost (ICC) of an item is the total cost of its purchase, operation, maintenance, servicing and disposal. A ICC program has been implemented by the Federal Supply Service. Procurements for the five products have included some partial form of LCC in their bid price. None of these LCC formulas considered all ownership costs, but they have included some costs other than initial costs.

The October, 1974 Invitation for Bid (IFB), sometimes referred to as a Request for Proposal (RFP), for gas ranges 2/ and the February, 1975

1/ President's Science and Technology Message of March 16, 1972.

2/ "Requirements Contract for FSC-7310 -- Ranges, gas operated freestanding" Solicitation No: FPGA-E-55545-N-11/21/74. 
Invitation for Bid for electric ranges $3 /$, are two of five procurements performed jointly by ETIP and FSS.

\subsection{Factors to be Evaluated}

In order to determine whether the Federal procurement process can be used to stimulate the marketing of energy-efficient products, ETIP has undertaken a program to evaluate its five procurement experiments. The Product Systems Analysis Division (PSAD) of NBS was asked by ETIP Personnel to assist it in its evaluation of gas and electric range procurements. PSAD's role in the evaluation was limited to conducting a survey of firms that manufacture household ranges. The survey was designed to include a sample of firms in the industry rather than just companies that bid on ETIP experiments. Information was sought on:

(A) Reasons for participation or non-participation of a company in the most recent FSS procurements,

(B) Problems that a manufacturer encountered with existing Federal procurement practices,

(C) Acceptability of using life-cycle costing in the bidding procedure,

(D) Effect of the most recent Government procurements on present and future company operations, including support for engineering and investment in research, types of themes used in advertising campaigns, etc.

The survey examined the outcome of the ETIP experiments as determined by the manufacturer responses in producing new product development in household ranges. The author was not involved in the design of the experiment and the particular life-cycle cost formula used. No attempt was made to evaluate whether the particular life-cycle cost formula utilized was the most effective mechanism for bringing about increases in the energy efficiency of ranges.

3/ "Requirements Contract for FSC-7310 -- Ranges, Electric, Household" Solicitation No. FPGA-C-55571-N-4/1/75.

These two documents can be obtained from the Business Service Center, General Services Administration, Room 1701, 7th and D Streets, S. W., Washington, D. C. 20407. 


\subsection{Range Procurement Methodology}

Previous FSS procurements of gas and electric ranges had been awarded solely to the lowest bids that met the IFB specifications. The total cost of ownership was not included in these previous bids. The bids of the two IFB's being studied were computed in terms of a modified life-cycle cost formula.

The FSS does not purchase ranges directly from the successful bidder, but only identifies the item and the contractor in a FSS supply schedule, from which Government agencies make purchases. In order for a company to be placed on a supply schedule they must successfully bid on the procurements.

The estimated number of residential-type ranges to be purchased by Government agencies for the experimental procurement was estimated at 22,200 gas ranges and 3,720 electric ranges. These represent approximately one year's purchases for the period beginning February 1975 for gas ranges and July 1975 for electric ranges. Bids in these procurements were requested for 10 regions in the U.S. for the following model sizes: $51,76,91$, and $102 \mathrm{~cm} .(20,30,36$, and 40 inch) gas ranges; and $51,60,76$, and $102 \mathrm{~cm}$. $(20,24,30$, and 40 inch) electric ranges.

Eight firms bid on the gas range procurement. Three of these firms received FSS contracts. Five firms bid on the electric range procurement and two received FSS contracts.

\section{Methodology}

\subsection{Questionnaire Development}

A preliminary set of questions was derived from discussions with ETIP staff. Experience gained from a previous ETIP evaluation was also useful in the design of the survey. 4/ Suggestions for questions in the survey were sought from members of the Product Standards Development Section of PSAD and representatives of FSS. Representatives of the Gas Appliance Manufacturers Association (GAMA) and the Association of Home Appliance Manufacturers (AHAM) reviewed and concurred with all of the survey questions. A final draft based on the results of these meetings was reviewed by ETIP and became the final version of the questionnaire as that was used in the survey (Appendix A).

\subsection{Sample Selection}

Companies considered for participation in the survey were selected from lists provided by GAMA, AHAM, and FSS of gas and electric range

4) Unpublished manuscript, C. Fried, F. Bents, and T. Fody,

"Survey of Window Air Conditioner Manufacturers," June 1975. 
manufacturers. Combined, these three lists included a complete list of domestic gas and electric range manufacturers.

Because of time and money contraints it was decided that the final sample size would be nine firms. These firms were to include a representation of both bidders and non-bidders, as well as large and small manufacturers. The three largest gas range manufacturers (as measured by their percent of sales in the gas range market) were selected. All three of these companies were also large manufacturers (over 5 percent of the market) of electric ranges. Both the gas and electric range procurements had several bidders (eight for gas and five for electric), and of these four gas bidders and three electric bidders were randomly selected. Two of the firms were bidders of both procurements, so a total of five firms had bid on at least one of the procurements. Two of the five bidders were also large manufacturers so the remaining sample (three additional firms) was drawn randomly from the lists discussed above. All nine of the manufacturers chosen were surveyed between August and September 1975 (See Appendix B for list of manufacturers.)

\subsection{Data Collection}

Prior to the first contact by a survey team member, each of the companies scheduled to be visited was sent the letter shown in Appendix C. The company official to whom the letter was addressed was designated by GAMA or AHAM as the appropriate contact. Shortly after the letters were sent, telephone calls were placed to each of the officials to whom the letters had been addressed. The caller further described the purpose of the proposed meeting and requested that company representatives attend the meeting who were familiar with Government procurement. In addition, officials from the marketing and engineering departments of the company were asked to attend, if possible. The number of executives interviewed at a session ranged from one to five individuals, depending on the complexity of the company's organization.

The interviews began with a brief account of the motivation for the modified procurement experiment and the purpose of the survey. A standard explanatory paragraph was read to all participants (Appendix D). Participants were also told that they would receive a copy of the final report after it was published.

The interviews were conducted in an open-ended maner, generally lasting from two to three hours. The interviewer read each question to all participants at the same time. All of the companies were cooperative and helpful. 


\section{Survey Results}

\subsection{Background: The Range Industry}

There are over 30 gas and electric range manufacturers in the United States. Of these manufacturers, the major share produce both gas and electric products. In this survey both gas and electric manufacturers are treated as a single entity, whenever possible. One of the firms in the sample produced only gas ranges (no electric range production) and two produced only electric ranges.* Even though the sample was mixed, it was unnecessary to differentiate between gas, electric, and gas and electric range manufacturers for most questions.

Consumers have become more interested in middle and top of the line models that contain more features. Self-cleaning and continuous-cleaning ovens have had a tremendous impact on the household range market. These features are extremely common, and only the bottom line models offer conventional ovens. Ceramic top ranges are also gaining popularity.

Based on discussions with the gas and electric range manufacturers, it appears that a definite interest in obtaining Government business does exist. This is shown in Table 1.

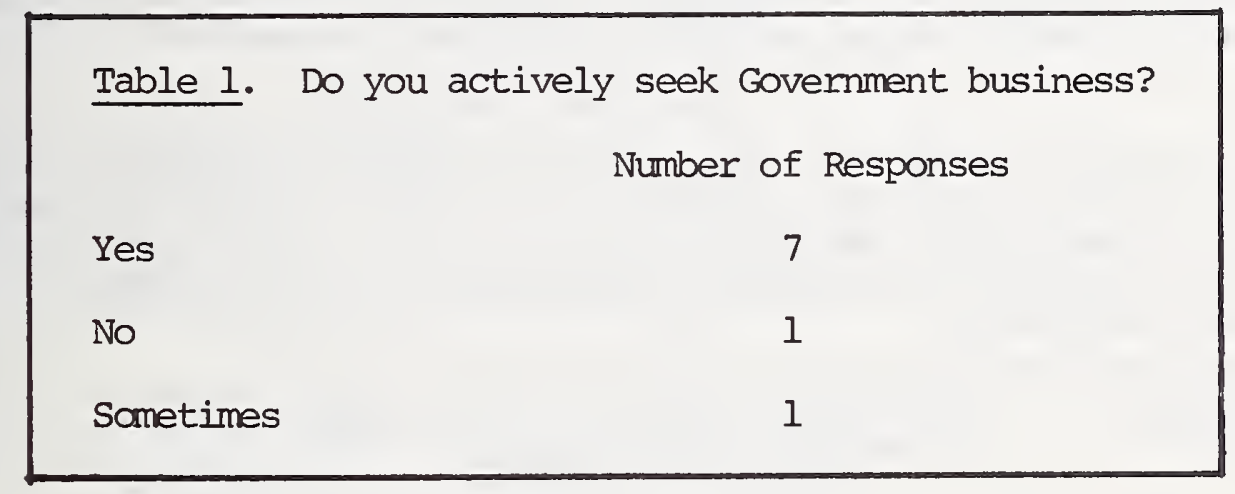

*Occasionally a manufacturer who produces only one type of range (e.g. electric) may purchase the other type (e.g. gas) of range and label them with their own brand name. This is done for marketing purposes. 
However, as shown in Table 2, Government purchases do not account for a large percentage of sales for most of the surveyed manufacturers.

\begin{tabular}{|c|c|}
\hline \multirow[t]{2}{*}{ Table 2.} & $\begin{array}{l}\text { What percentage of your total } \\
\text { company business is Government } \\
\text { range business? }\end{array}$ \\
\hline & Number of Responses \\
\hline None (or pract & ically none) \\
\hline Less than $1 \%$ & 4 \\
\hline $2-8 \%$ & 3 \\
\hline $9-14 \%$ & 0 \\
\hline More than $15 \%$ & 1 \\
\hline
\end{tabular}

These percentages given above include all Federal Government purchases and are not limited to FSS contracts. FSS is not the only procurement office for Government ranges, since the Department of Housing and Urban Development (HUD) has its own procurement mechanism. An inquiry was made to determine the percentage of Federal range purchases which were represented by this FSS contract, however this information was not available.

Of the nine firms contacted, three used more than one method to obtain information about Government procurements. The remaining firms used only mailing lists -- such as the FSS bidders list. Table 3 lists the methods for obtaining information on Government procurements and the number of firms that use each method. Table 3. How do you find out about specific
Government procurements?

Number of Responses*

FSS bidders list

(receive copies of

IFB directly)

Other mailing lists (HUD etc.) 9

Conmerce Business Daily $\quad 1$

Personal contacts 2

Trade Association Newsletters 1

*The total number of replies exceeds nine when one or more companies provide more than one response. 


\subsection{The Government Procurement Mechanism}

\subsubsection{Industry Problems}

Eight of the nine companies indicated that there were difficulties in doing business with the Government attributable to the Government's purchasing procedures. Table 4 summarizes some of these problems. All nine companies had some knowledge of the Government bidding process.

Table 4.
Do you think Government purchasing procedures make it difficult, or actually discourage, doing business with the Government? All respondents replied "yes", so they were asked for details.

Number of Responses*

1. Specification Problems

Non-standard specifications

References are made to other speci-

fications not included in IFB (RFB)

Too many different specifications

2. Paperwork and Manpower Problems

Too much paperwork

Statements in IFB are difficult to follow

Waiting for federal inspector is inconvenient

3. Burdensom requirements in order

to participate

Verification of test data is difficult 1

Unnecessary testing required

Shipping of very small numbers

should not be required

Shipping (different from

normal procedures)
3

1

\section{4}

2

1

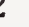

1

2

*The total number of replies exceeds nine when one or more companies provide more than one response.

Several companies felt that the Government gains very litte, if anything, in the way of better performance or quality by stipulating procurement specifications which differ from "standard" production models (e.g., porcelain oven coupled with a luxury lighted backsplash -- not a standard item). Bids for procurements with non-standard specifications require excessive amounts of engineering and administrative manpower. This is felt to be an unnecessary loss if the company's bid is not won. 
One firm's representative objected to the system of including shipping cost factors by zones in the bid. He said this system gives an advantage to manufacturers closest to the zones with highest purchases and also that sporadic staggered orders within a given zone increase the shipping charges. A second company stated that it should not be required to ship only one range to a location at a time.

Government required product testing was mentioned as being of questionable value. One firm stated that destructive testing should not be required prior to the award of a contract. Another firm said that destructive testing should not be required at all. Four companies claimed that AHAM, AGA, or UL testing requirements were sufficient, and that the Government should accept these requirements rather than duplicate them with additional testing of its own. Table 5 summarizes these views on product testing.

Table 5. Suggestions for reducing costs of testing products. Number of responses

Use only AHAM, AGA, or UL testing requirements

Continue separate Government testing

No answer given

Several companies suggested that Government could get a greater response to its IFB's if it were to use existing AGA, or UL standards, eliminating the development of special model designs. The general feeling was that Government business is not significant enough to make the redesign of assembly-line products worthwhile. Table 6 summarizes the suggestions made by the respondents on how Government might get increased participation. 
Table 6. What do you think the Government could do to increase the number of responses to its IF''s

Number of Responses*

Simplify the bidding procedure 5

Accept AGA and UL standards and specifications

Make specifications and IFB

more readable

Require only standard size ranges $\quad 1$

Eliminate inspection procedures $\quad I$

Add the continuous cleaning feature 1

No answer, Government should not seek to encourage participation

*The total number of replies exceeds nine when one or more companies provide more than one response. 


\subsubsection{Factors in the Decision to Bid on an IF'B}

The decision to respond to an IFB was reported to be based on one or more of the factors shown in Table 7 .

Table 7. If you bid on a given contract what are the prime factors in your decision?

(What made you bid on these contracts?)

Number of Responses*

Company has a product available

with which they can possibly

win the IFB

Company meets all necessary

Government specifications

(including requirement dates)

Company feels it will make a

profit from the contract

Company needs additional business 2

Company feels it has a public

responsibility to bid

Inventory levels of the company 1

*The total number of replies exceeds nine when one or more companies provide more than one response.

All firms interviewed produced Government bought ranges as part of their regular production lines. No company had an engineering department exclusively devoted to Federal purchases. Several firms had one or more persons who dealt with Government bids. At least one company indicated that Federal procurements, with their special requirements, necessitated separate treatment. 
The firms surveyed were asked to state what criteria they would recommend FSS use in its future procurements of gas and electric ranges.

Table 8. If you were in Federal Procurement, how would you purchase ranges? What factors would you use?

\section{Number of Responses*}

Life-cycle costing approach 3

Price 3

Performance or Quality 3

Serviceability 3

Maintenance costs and parts 2

Reliable manufacturer 4

Ability of manufacturer to meet schedule

Standard product offered to the public 1

Ability to meet AGA \& UL standards 3

Appearance 1

Durability 1

Multi-award system 1

*The total number of replies exceeds nine when one or more companies provide more than one response.

Three respondents mentioned life-cycle costing as a possible criterion for purchasing ranges. Several others indicated that they would use the proposed factors in a life-cycle costing formula, such as price, performance, serviceability, or maintenance costs. These firms also indicated that life-cycle costing should include a factor of energy efficiency. 


\subsection{Life-cycle costing}

\subsubsection{The LCC Formula}

A life-cycle cost (ICC) was used in the bid price in responding to the IFB for both gas and electric ranges. The formula for the ICC was designed by FSS and was not meant to represent a complete formulation including all ownership costs. The ICC formulation consisted of initial purchase price plus a discounted cost of energy to operate the ranges for an assumed life of twelve years. The ICC formula was identical for both gas and electric ranges. As quoted in the IFB's, the ICC formula is $\mathrm{L}=\mathrm{X}+\mathrm{Y}$

"where

$\mathrm{L}=$ Life-cycle cost (present value dollars) of a product

$\mathrm{X}=$ Initial cost of product according to submitted bid price

$Y=$ Present value sum of the annual operating cost $(y)$ of the product over its expected life

Operating cost, $y$, for both gas and electric ranges will be computed through the methods described herein, although

certain parameters will be assigned different values

depending upon the type of range being evaluated." 5/

The value to be used for $y$ is computed from a formula (reproduced in Appendix E) incorporating range surface and oven requirements for energy to cook food for both gas and electric ranges.

Although the respondents did show an interest in the ICC concept they also showed some reserve with regard to its application to ranges. Concern centered on the difficulty in defining normal usage (determining a value for $Y$ ) which affected by variables such as oven and surface element sizes as well as cooking utensil size, shape, and condition. The degree to which any accumulated test data represented a real-life situation was questioned.

Only one company indicated satisfaction with the current Government LCC formula. However, only one company showed strong opposition to the use of some type of life-cycle costing in Govermment procurements. The remaining companies indicated some interest in the concept of life-cycle costing but felt that the present formula was insufficient. All of these firms claimed that more data should be collected on average usage, and that research was needed to determine if normal operating costs, can in fact, be measured at all. One firm felt that FSS should eliminate the LCC formula from all household range procurements until AHAM has developed an acceptable formula.

5/ "Requirements Contract for FSC-7310 -- Ranges, gas operated freestanding" Solicitation No." FPGA-E55545-N-11/21/74.

"Requirements Contract for FSC-7310 -- Ranges, Electric, Household" Solicitation No. FPGA-C-55571-N-4/1/75. 
The LCC formula assumes a twelve year product life for both gas and electric ranges. The respondents varied on what they felt was an accurate estimate of the life expectancy of a range. The companies' estimates varied from 10 to 20 years, with some firms giving gas higher estimates than electric ranges. None of the firms were sure enough of their estimates so they could disagree with the arbitrary twelve years given in the ICC formula. Several indicated that the life is shortened simply because ranges tend to be replaced for reasons other than mechanical breakage such as the ranges appearance.

Seven of the nine respondents said they would be interested in a presentation on the ICC formula by FSS.

\subsubsection{Maintenance Data}

More data than is currently available is needed for FSS to include maintenance or service costs in the LCC formula. The next question (Table 9) attempted to find out if such data are collected by the companies that were interviewed.

Table 9. Does your company determine maintenance data for ranges?

Number of Responses

No

Yes, very limited data

Yes, during the warranty period only

Yes, warranty period plus some additional part replacement data 1

In most cases, the firms would probably refuse or hesitate to release such service data to FSS for use in its computation of life-cycle costing. Table 10 clearly indicates this hesitation. 


\begin{tabular}{|c|c|}
\hline & Number of Responses \\
\hline Yes & 1 \\
\hline Maybe & 3 \\
\hline Probably not & 1 \\
\hline No & 2 \\
\hline No answer given & 2 \\
\hline
\end{tabular}

If FSS were to rely upon the manufacturers to supply data on maintainability, the responses above indicated that the manufacturers would not or would not be able to supply the necessary data to extend the ICC formula beyond initial and operating cost.

\subsubsection{Warranty Information}

All nine companies indicated that the Government could obtain whatever warranty it desired if it were willing to pay for it. In most cases, warranties provided to the Government were similar to or slightly better than those offered to private consumers.

When asked if the Government makes use of its warranties; one company indicated that the Government rarely uses them; two companies stated that the Government did, but were unsure of how often; the remaining companies were unsure or had no experience. The records of most companies did not allow a comparison to be made between consumer and Government warranty usage data.

The percentage of the range price used to pay the expense of the warranty depended on the model offered. The amounts varied from less than one percent to nearly ten percent for some models. When asked if their company would lower its bid price if the Government waived the warranty, 6 companies said they would, while the remaining 3 said they would not.

\subsection{Bidders' Conferences}

The Pre-bidding Conference is designed to provide FSS with a chance to discuss the required specifications with industry and to explain the bidding process and the ICC formula. 
All of the companies felt that firms represented would not openly discuss their ideas at such a conference. Several interviewees said that they would be very careful as to what they said in front of their competitors. Six indicated that Bidders' Conferences would not be beneficial to the Government in obtaining industry's reactions to IFB specifications.

Some companies said they would consider attending a bidders' meeting; others were unsure as to their interest in attending; two said they would not attend under any condition. At least three companies indicated a preference for individual sessions with FSS over group meetings. One company felt Bidders' Conferences should be held only for extremely large bids.

\subsection{Advertising}

The discussion on advertising elicited a variety of responses. Several firms were unsure of their answers and changed them during the discussion. A GSA regulation prohibits a firm from advertising a Government procurement if a suggestion is made that the Government endorses or prefers the product or considers it to be superior to other products. (Appendix E).

Table 11. If you were awarded a contract by FSS for a product containing a new technology, would you want the Government to advertise this fact?

\section{Number of Responses}

Yes

Unsure

No

No answer, would not produce

a new technology

The responses to the above question showed considerable variations. One firm that was interested in having the Government advertise the award felt that only consumers should be informed; the second felt only Government publications should include the advertisements; the third felt that the Government should not release any technical data to competitors. The remaining respondents felt that the Government should stay out of advertising. 
One question in the survey attempted to determine if relaxing the prohibition against advertisement of winning a FSS procurement would be an added inducement to bid on future procurements. A large share of the firms indicated that this would not be an incentive. One firm felt that any advertising of the award would be unfair to manufacturers who did not bid. This is shown in Table 12 .

\begin{tabular}{|c|c|}
\hline Table 12. & $\begin{array}{l}\text { If a successful bidder were able to } \\
\text { advertise a FSS Procurement would } \\
\text { this be an added incentive to bid? } \\
\text { Number of Responses }\end{array}$ \\
\hline Yes & 2 \\
\hline No & 7 \\
\hline
\end{tabular}

\subsection{Engineering Considerations}

Several of the respondents named problems that they felt were due to technical factors included in the gas and electric range procurements. This is illustrated by the answers referenced in Table 13.

Table 13. Do you think the concern for energy efficiency implicit in the RFP was sufficient?

Number of Responses*

Yes:

The RFP was sufficiently concerned with energy efficiency.

No:

(I) The LCC formula was not technically sound 2

(2) Assumptions made in the RFP were incorrect 2

(3) More time should be spent developing

a more representative LCC formula

(4) More detail should be included in an ICC formula, if one is going to be used

No answer

*The total number of replies exceeds nine when one or more companies provide more than one response. 
All of the manufacturers said that more energy efficient ranges will involve considerable engineering expense and effort. The technology presently exists for some changes that would increase energy efficiency, but the manufacturers felt that the price of such models would be a deterrent to the consumer. At least one company felt that energy related basic research involved huge amounts of money and facilities, both of which are hard to obtain.

Several suggestions were made as to how to make ranges more energy efficient. The following were suggested: (a) additional insulation; (b) electric ignition, instead of pilot lights; (c) convection ovens; (d) smaller ovens; (e) less input of energy to burners; (f) "thermal conductive resistant" finishes; ( $g$ ) more efficient elements (better heat transfer). One company felt that the most effective way to reduce energy consumption of ranges is to educate the public to reduce the amount of BTU's they use while cooking.

All companies were familiar with the pilotless range. More than half of the companies already had a pilotless range or were considering the introduction of such a model into their product line.

Two of the nine firms said that their engineering staffs were of sufficient size and competence to respond to any engineering efficiency programs. The other firms stated that they spent some time on energy research but felt that other priorities needed greater involvement of their engineering staff. Most of the companies were engaged in a research and development effort, but it was usually a part of the regular engineering program. Many of the firms used outside consultants or engineering firms to assist with their research and development. None of the firms had a separate engineering effort for Government contracts.

\section{Discussion}

The primary objective of the ETIP procurement experiments with gas and electric ranges was to determine if the Government procurement mechanism could be used to bring about the development of more energy efficient range models than were previously (to the procurement experiment) available. Since no new range models with significant energy efficiency usage improvements were bid, and no new energy efficient models are to be introduced to consumers, as a result of the experiment, in the immediate future, we cannot conclude that the experiment was successful.

There are a number of factors that may account for the lack of success. The Federal Government exerts only a limited amount of leverage in the range industry marketplace. Consequently, the profits to be realized from selling an energy-efficient range to the Government may be insufficient to offset the large (capital) investments required to produce such a model, assuming that significant gains in energy efficiency cannot be realized with minor modifications to exisiting model lines. 
A very significant factor for determining range model lines available is the demands of the consuming public, which in turn are influenced by promotional efforts by the manufacturers and technological breakthroughs.

There are a number of other factors that probably contributed to the lack of success of the ETIP procurement experiment. Chief among these was the lack of agreement between ETIP on the one hand and the range manufacturers on the other regarding the appropriateness of the ICC formula used in the procurement. In particular, there was disagreement over what the appropriate mechanism should be for determining energy usage costs.

On the encouraging side, a number of manufacturers stated they were pleased that the Government is experimenting with life-cycle cost purchasing rather than the lowest initial price to purchase gas and electric ranges. A few said this might influence the responding to future Government procurements. A number of firms indicated they were introducing energy savings devices on new models, but that this was in response to perceived (by manufacturers) consumer demands, as well as other Federal programs to encourage more efficient energy use. In sumary, FSS/ETIP procurements for ranges have met with positive response by industry, who would like to see the ICC formula improved upon. Improvement of the LCC formula would probably increase the Government's opportunity to obtain lower life-cycle cost ranges. However, this probably would not inf.luence manufacturers to introduce new energy efficient technology. 


\section{APPENDIX A}

Questonnaire for Manufacturers of Gas and Electric Ranges

I. Sales and Market

1. What are the total sales of gas and electric ranges (in units) in the U.S.? Do you have them for this year and the two previous years? If not, where can I obtain this data?

(Note: only ask this question of one company.)

2. What percentage of your overall operation is Govermment business?

3. Do you actively seek Govermment business?

4. How do you find out about specific Government procurements? i.e., Commerce Business Daily; trade association newsletters, etc.

5. Do you read the Commerce Business Daily regularly?

6. WINNING BIDDERS ONLY: Will the appliance produced in fulfillment of this contract get into the consumer market?

IF NO: Why not?

IF YES: Will an advertising campaign accompany it, calling attention to its energy-saving qualities.

NON-WINNING BIDDERS ONLY: Did you intend to enter the appliance which would have satisfied the contract into the consumer market?

II. Procurement Mechanism

1. Have you previously bid on a Govermment contract?

IF YES: What product?

2. Do you think Government purchasing procedures make it difficult, or actually discourage, doing business with the Government?

IF YES, ASK FOR DETAIIS AND SPECIFIC PAST EXPERIENCES.

3. If you do bid on a given contract, what are the prime factors in the decision?

4. What made you bid or not bid on this contract?

5. What do you think the Government could do to increase the number of responses to its RFP's? 
6. Does your company treat Govermment business as a separate market from consumer business? How? In what way?

7. If the type of procurement use in this REP continues to be used, will it change your policies vis-vis Government business?

8. What suggestions do you have for reducing the cost of testing ranges.

9. What company policies, if any, will be effected by the procurement procedures used in the ETIP experiment? What effect? How, if at all, will the following areas be affected?

Research and Development
Design and Marketing
Marketing
Advertising
Related Product Lines
Other

10. If you were in Federal Procurement, how would you purchase ranges? What factors would you use?

11. How would you like to see the Government construct a life_cycle cost formula?

12. Would you be interested in receiving a Government presentation on LCC?

13. What is the life expectancy of household ranges?

14. Does your company determine maintenance cost data for its products?

IF YES, ASK FOR DETAIIS.

15. Is this data available to the Govermment?

16. If you were dealing with the Govermment, would it get the same warranty as the consumer?

17. What percentage of your Govermment business makes use of its warranty?

18. What percentage of your unit costs is represented by the warranty?

19. If the Government didn't want a warranty, would this be reflected as a lower initial bid? 
III. Pre-Bid Discussion

1. How successful do you think Bidders' Conferences would be in obtaining industry inputs regarding Government specifications?

2. Would our company attend? IF NO: Why Not?

3. Do you think industry would openly discuss its ideas at such a conference? What are your ideas on the topic of Bidders Conferences in general?

IV. Advertising

1. If you were awarded a contract by the Government for a product containing new technology, would you want the Government to advertise this fact?

IF YES: How would you prefer it to be done?

IF NO: Why not?

2. If a successful bidder were able to advertise and ETIP/FSS Procurement, would this be an added incentive to bid?

3. Can you suggest other ways in which the Government might advertise its new procurements?

V. Engineering

1. Do you think the concern for energy efficiency implicit in the RFP (IFB) was sufficient (i.e., in terms of what could be done)? Should other performance factors have been used?

2. Do you feel that the capability exists now to produce a more energy-efficient appliance without the need for major engineering innovations?

IF YES: What do you think is holding it back?

IF NO: Do you think there is an adequate industry-wide engineering effort toward that end?

IF NO: What do you think is the reason?

3. How can gas and electric ranges be made more energy-efficient?

4. Is your engineering staff of sufficient size and professional level to be able to respond to efficiency programs utilizing current state-of-the-art technology? 
5. Is there a separate engineering effort for Government contracts?

6. Are you engaged in any R\&D effort?

IF YES: Do you have a separate R\&D staff?

How large? Is R\&D an additional duty of the engineering staff?

7. What do you think can be done to encourage the industry as a whole to adopt a new energy-conscious ethic in its design philosophy?

GAS RANGES: Is there an industry effort to improve the efficiency of pilot lights? IF NO: Why not, since it has been shown that pilot lights use a large percentage of the energy consumed by gas ranges? IF YES: Could you explain what it entails? 


\section{APPENDIX B}

List of Firms that Participated in the Survey

Brown Stove Works, Inc.

P.O. Box 490

Cleveland, Tennessee 37311

Caloric Corporation

Meeting House Road

Topton, Pennsylvania 19562

Crown Stove Works, Inc.

4627-35 W. 12th Place

Chicago, Illinois 60650

Frigidaire Division

General Motors Corporation

300 Taylor Street

Dayton, Ohio 45401

General Electric Company

Appliance Park

Louisville, Kentucky 40225

Magic Chef, Inc.

740 King Edward Avenue

Cleveland, Tennessee 37311

Roper Corporation

1905 West Court Street

Kankakee, Illinois 60901

Sunray Stove Company

Division of Glenwood Range Company

Delaware, Ohio 43015

The Tappan company

Tappan Park

Mansfield, Ohio 44901 
APPENDIX C

Letter Mailed to Request Participation

August 7, 1975

Dear:

In August of last year, the Federal Supply Service requested technical proposals and bids for gas and electric ranges. This procurement was initiated under the Experimental Technology Incentives Program (ETIP), and was one of several experiments designed to investigate the efficacy of stimulating the rate of entry of new technology into the marketplace via Government procurement procedures.

These experimental procurements conducted by the Federal Supply Service have not yet been evaluated to determine their effect on future product development; consequently, ETIP and the Federal Supply Service are seeking to collect information to help evaluate the program. Specifically, we would like to visit your firm and speak with one or more people in order to collect basic information.

The type of information we are concerned with relates to the reasons your firm did or did not participate in this procurement. Your organization's views on the suitability and utility of achieving accelerated product development through this experimental mechanism will also be discussed. More sensitive information, such as your firm's future design and production plans, current $\mathrm{R} \& \mathrm{D}$ effort, or marketing and advertising strategies may be discussed if it appears that this information might provide quantifiable evidence or program impact. Because of the range of topics, discussion with a member of both engineering and market research departments would probably be desirable.

All information collected from participating firms will be controlled by the National Bureau of Standards and not released in its basic form within NBS or elsewhere. The information will be summarized and presented in a form that will not disclose the views, opinions or market profile of individual participants. Participating organizations will receive copies of the report after printing.

I hope that your firm will be able to participate in the evaluative phase of this program. A minimum of time should be involved and the results on the analysis could be of value to all of us. I would appreciate hearing from you at your convenience concerning who should be contacted in regard to the data collection aspect of the evaluation.

Sincerely,

Theodore J. Fody

Chief, Procurement Policy Area

Experimental Technology Incentives Program 


\section{APPENDIX D \\ Introductory Paragraph Read to Respondents}

The Federal Supply Service is currently involved in a number of experiments to determine whether the rate of entry of new technologies into the consumer marketplace can be stimulated by means of Government procurements. As part of these experiments, bids for gas and electric ranges were recently solicited. (Show copy of RFP/IFB.)

The National Bureau of Standards has been asked to evaluate these procurement experiments. As part of this evaluation, we are speaking with people from a number of firms in the industry. We are interested in finding out whether the procurement approach taken by the ETIP is practical and effective, and are particularly interested in learning industry's viewpoints on the matter. Your answers to the following questions will help us in the program evaluation. All the information you provide us will be controlled at NBS, and will remain anonymous as to company identification. The report generated by this evaluation will be in summary form, without individual companies being specifically identified; of course, your firm will receive a copy. 


\section{APPENDIX E}

\section{Methodology for Calculating LCC*}

Taking " $y$ " and the 12-year product life, the present value sum of operating costs, Y, will be computed as:

Sum of discount factors for years 1 through 12, at a rate of 10 percent, is $\underline{6.814}$. Therefore,

$Y=(6.814) Y$

Where $y=\frac{(\text { Ens }}{(\text { ET }}+\frac{\text { Eno })}{\text { Eo })} C$, and

Ent = Ens + Eno = Average total energy needed to cook food for 1 year $4.009 \times 106 \mathrm{BTU}=40.09$ THERMS (for Electric Ranges)

$9.809 \times 106$ BTU $=98.09$ THERMS (for Gas Ranges)

( 1 THERM $=100,000 \mathrm{BTU} ; 1 \mathrm{KWH}=3412 \mathrm{BTU}$ )

Ens = Average total energy needed to cook food on range surface units.

Eno = Average total energy needed to cook food in a range oven.

$E T=$ Average total thermal efficiency of the surface units of one range (expressed as decimal portion of 1.00).

Eo = Thermal efficiency of one range oven (expressed as decimal portion of 1.00$)$.

$\mathrm{C}=$ Cost per THERM (see RATES FOR COMPUTING ICC in the IFB)

Ens $=26.73$ Therms (for Electric Ranges).

65.39 Therms (for Gas Ranges)

Eno $=13.36$ Therms (for Electric Ranges)

32.70 Therms (for Gas Ranges)

*Quoted from "Requirements Contract for FSC-7310 -- Ranges, gas operated freestanding" Solicitation No: FPGA-E-55545-N-11/21/74. and

"Requirements Contract for FSC-7310 -- Ranges, Electric, Household" Solicitation No. FPGA-C-55571-N-4/1/75. 


\section{APPENDIX F \\ Government Regulation on Advertising}

Current Clause 44 of Form 1424: Advertising of Award

"44. The contractor agrees not to refer to awards in conmercial advertising in such a manner as to state or inply that the product or service provided is endorsed or preferred by the Federal Government or is considered by the Govermment to be superior to other products or services." 


\begin{tabular}{|c|c|c|c|}
\hline $\begin{array}{l}\text { U.S. OEPT. OF COMM. } \\
\text { BIBLIOGRAPHIC DATA } \\
\text { SHEET }\end{array}$ & $\begin{array}{l}\text { 1. PUBILICATION OR RI:PORT NO. } \\
\text { NBSIR 76-1027 }\end{array}$ & $\begin{array}{l}\text { 2. Gov't Accession } \\
\text { No. }\end{array}$ & 3. Recipient's Accession No. \\
\hline \multicolumn{3}{|c|}{$\begin{array}{l}\text { 4. TITLE AND SUBTITIE: } \\
\text { A Survey of Manufacturers' Views on the ETIP Procurement } \\
\text { Experiment. Volume Three: Ranges }\end{array}$} & 5. Publication Date \\
\hline \multicolumn{3}{|c|}{ 7. AUTHOR(S) P. Clare Goodman } & $\begin{array}{l}\text { 8. Performing Organ. Report No. } \\
\text { NBSIR 76-1027 }\end{array}$ \\
\hline \multicolumn{3}{|c|}{$\begin{array}{l}\text { 9. PERFORMING ORGANIZATION NAME AND ADDRESS } \\
\qquad \begin{array}{l}\text { NATIONAL BUREAU OF STANDARDS } \\
\text { DEPARTMENT OF COMMERCE } \\
\text { WASHINGTON, D.C. } 20234\end{array}\end{array}$} & 10. Project/Task/Work Unit No. \\
\hline \multirow{2}{*}{\multicolumn{3}{|c|}{$\begin{array}{l}\text { 12. Sponsoring Organization Name and Complete Address (Street, City, State, ZIP) } \\
\text { Experimental Technology Incentives Program } \\
\text { National Bureau of Standards } \\
\text { Washington, D. C. } 20234\end{array}$}} & $\begin{array}{l}\text { 13. Type of Report \& Period } \\
\text { Covered } \\
\text { Final }\end{array}$ \\
\hline & & & 14. Sponsoring Agency Code \\
\hline
\end{tabular}

15. SUPPLEMENTARY NOTES

16. ABSTRACT (A 200-word or less factual summary of most significant information. If document includes a significant bibliography or literature survey, mention it here.)

This report describes the findings of a survey of nine gas and electric range manufacturers by the center for Consumer Product Technology. The survey was conducted for the Experimental Technology Incentives Program (ETIP) as part of its evaluation of a Federal Supply Service (FSS) procurement of ranges. Survey questions were designed to obtain manufacturers' views on the use of Government procurement policies to increase the rate of introduction of new technologies into the consumer marketplace. The questions covered the following areas: (1) reasons for participation or non-participation of a manufacturer in the ETIP experiment; (2) problems a manufacturer encounters with existing Federal procurement practices; (3) acceptability of using life-cycle costing in the bidding procedure; and (4) effect of the most recent Government procurement on present and future company operations. Results of the survey are reported, and inplications are drawn for future EIIP studies of Government procurement activities.

17. KEY WORDS (six to twelve entries; alphabetical order; capitalize only the first letter of the first key word unless a proper name; separated by semicolons)

Energy-efficient products; Experimental Technology Incentives Program; gas and electric ranges; life-cycle costing; procurement experiments.

\begin{tabular}{|c|c|}
$\begin{array}{c}\text { 19. SECURITY CLASS } \\
\text { (THIS REPURT) } \\
\text { is }\end{array}$ & 21. NO. OF PAGES \\
UNCL ASSIFIED & 31 \\
\hline $\begin{array}{c}\text { 20. SECURITY CLASS } \\
\text { (THIS PAGE) } \\
\text { is } \\
\text { UNCLASSIFIED }\end{array}$ & 22. Price \\
$\$ 44.00$ \\
\hline
\end{tabular}

